maggot gained this place by entering through the stigma from outside.

My investigations extend from April 1883 to June of this year, and are briefly summed up as follows:-

Udschimya sericaria appears generally in the middle of A pril, and attains maturity in the beginning of May, at the time when mulberry-trees expand their spring leaves. The female flies, flying in bushes of mulberry-trees during the months of May and June, deposit their eggs on the under surface of the leaves in close contact with the mid-rib, or else with the fine ramified veins.

The eggs are nearly oval in shape, tapering at one end, and rounded at the other. They are very small in size, measuring $0.18 \mathrm{~mm}$. in length, and $0.13 \mathrm{~mm}$. in breadth, and generally convex on the upper and flat on the under surface. The upper convex surface, which is coloured blackish-brown, has a lustre, and is marked out into hexagonal areas ; while the lower flat surface, which is coloured grayish-brown, lacks lustre, and is only faintly marked out into hexagonal areas. The whole egg is enveloped with a sticky substance, which fixes it firmly with its flat side on the under surface of the leaves.

When the leaves on which the eggs are thus deposited are given to the silkworms, they eat them whole along with the leaves, without crushing them at all. At one to six hours after the eggs are taken, they are hatched out near either end of the digestive canal, and a tiny white maggot comes into existence. After a while the maggot passes out of the alimentary canal through the mucous membrane, with the aid of its horny hooked tooth and of setæ provided on cach segment, and enters directly into one of the nervous ganglia found just under the digestive canal. A thin transparent membrane which envelops the ganglion becomes a protecting sac, inside which the maggot lives, and takes nerve-cells as its food. As it grows in size, this sac gradually enlarges, and finally rupturing, the maggot passes out into the body-cavity. At this time it measures five to six millimetres in length.

The maggot now seeks the main stem of the trachea, which forms a kind of chamber just inside the stigma of the silkworm, and enters into it by making an opening with its hooked tooth. It now sticks its head out into the body-cavity of the silkworm through the opening by which it entered, and takes fat as its food. Its posterior end, which is provided with two large spiracles, is directed towards the stigma, and thus the maggot respires the air which passes in through the latter.

As the maggot grows, this newly-formed chamb $r$ in which it rests also becomes larger, and the opening through which the anterior end of the maggot is projected out into the body-cavity of the silkworm becomes wider and wider, until the chamber assumes the shape of a cup Around this cup a large amount of fat is fixed by the maggot, probably with a watery fluid it secretes of alkaline reaction, and thus the wall of the cup increases in thickness and becomes very tough. The wall is always coloured dark brown, owing prohably to the fæces of the parasite and to the action of the secretion upon the fat in the wall of the cup. In this position the maggot attains maturity; it then crawls out through an opening it makes at any portion of the bocy of its host. If, however, the growth of the maggot has been slow, it may be found in the trachea of the silkworm after it has changed into a pupa.

In either case, whether the larvæ or the pupæ have the parasite in the trachea, the space around the stigma, inside which the maggot is lodged, is always marked with a large dark brown patch, so that the presence of the maggot is easily recognised by looking at the stigma.

If a larva or a pupa of the silkworm is once infested by this parasite, its fate is scaled, and the cocoons made by the infested caterpillars are usually thin, and of much less valuc.

Those maggots which become mature in the pupæ of the silkworm crawl out of the cocoon by making a round opening at one pole, and such perforated cocoons are entirely useless for reeling silk.

The mature free magyot, coloured light yellow, is very active, and searching for the corner of the case in which they are kept, or crawling deep into the ground, changes soon into a black, cylindrical pupa. There the pupa rests through the winter, and in the following spring a perfected fly hatches out by breaking open the pupa-case.

A detailed account with suggestions for the remedies will soon be publisher in a Menoir of the University of Tokio.

University of Tokio, July

\section{Singular Instance of Instinct}

AMONG the insects very common to Victoria is one popularly known as the mason-1ly. In form it is very like a gigantic hornet; the wings and legs are of an orange colour, as is also the abdomen, which is decorated with broad black stripes. It has a strange habit of building its nest, composed of tempered mud, in keyholes. Mr. Ellery, F.R.S., the Government Astronomer, tells me that this same fly often commences to build within the tubes of their astronomical instruments. The nest is rather peculiar. A layer of mud is first laid down, and a certain number of eggs are laid. Then follows another layer of mud ; on this are deposited a number of young spiders, paralysed bu not killed. Another layer of mud, more eggs, then mud, then spiders again, and so on, until the nest is complete. The spiders are cvidently stored up as food for the grubs, as soon as hatched, an arrangement already known to naturalists. This fly has a very fierce aspect, and its nature evidently does not belie its looks. It flies about with great liveliness, and when alighting, its long black antennæe are kept in a state of constant motion. Its favourite food seems to be spiders, which it is in the habit of seeking for under the bark and in holes in the trunk of the Eucalyptus. It order to catch them it burrows under the loose bark, and in a few seconds generally issues forth again with some larg n: or smaller prey between its mandibles. The enormous bulk of some of the victims does not appear to intimidate it in the lcast. Even the gigantic so-called tarantula (vulgarly triantclope) is fearlessly attacked. I was one day walking through a suburban park near Melbourne, and saw one of these flics suddenly pounce down on the back of a large tarantula some five inches in breadth, measuring from the ends of the legs. The huge arachnidian succumbed at once. Resistance with an adversary in such a position was altogether out of the question, the only resource being to die, like Cæesar, becomingly. I watched the fight, or rather the murder, for some minutes, and then touching the assailant with the point of my umbrella, drove it away. It only flew, however, to a short distance, and then returned, flying so viciously round that I fully expected I should be attacked. By flourishing the umbrella, however, I again drove it off, and it retired to a distance of about a hundred feet. I then left the spider, but afterwards went back, and found the mason-fly following up his victory as energetically as ever. I drove it away again, left the spot, and again returned to find the murderous work still going on. This was repeated some half a dozen times, and at last, taking out a book, I sat down on a seat resolving to see what would happen. The fly did not reappear for nearly a quarter of an hour, and I thought it had altogether departed. A small ditch ran beside the pathway, and, turning my eyes in that direction, I noticed the mason-fiy peeping through some blades of grass growing on the edge. It was evidently waiting for me to leave the spot in order to secure the full advantages of its victory.

It may be mentioned that the tarantula is a great coward. Some of our large spiders, if placed on an ants' nest, will "run amuck" through the crowd, nipping with their immense mandibles scores of their assailants who may approach them. They will do this several times in succession, and generally get away. The tarantula, however, if placed in such a position, yields at once, and, gathering up its long legs, expires with all dignity. I have tried the experiment many times, when a run of six inches would have secured the freedom of the tarantula, but even in these cases no effort was ever made to escape. One species of spider, living under the bark of trees, the skin of the abdomen of which is very soft, often proves a match for the ants, not by fighting, but by stratagem. He plays his enemies a thoroughly Parthian trick, throwing out a number of webs, which completely entangle them. This same spider, if thrown into a pool of water, similarly throws out threads of web, and, these being wafted to the shore, and adhering to an overhanging branch, enable the spider to reach the land. THOMAS HARRISON

244, Victoria Parade, East Mclbourne, Victoria, July 9

\section{Przevalsky's Horse}

IT seems worth while to point out the close resemblance between the figure of this horse in NATURE for August 21 and those found incised on antlers in the cave of La Madelaine, copied in Dawkins" "Early Man." There is the same massive head, the same hog-mane, absence of forelock, pointed ears, short body, and powerful legs, while there seems even an indication that the long hairs of the tail spring first from the middle of that 